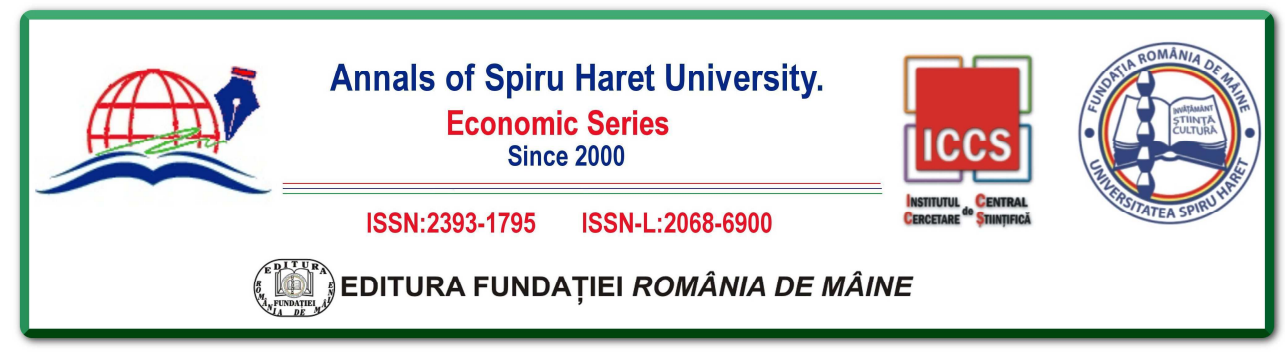

Issue 2/2018

\title{
RURAL EMPLOYMENT AND DECENT WORK IN ROMANIA
}

\author{
Laura PATACHE ${ }^{1}$, Claudiu CHIRU ${ }^{2}$, Mihaela BEBEȘELEA ${ }^{3}$ \\ ${ }^{1}$ Spiru Haret University, Unirii 32-34 Street, 900532, Constanta, \\ Romania, Tel: +40241545015; Email: laura.patache@spiruharet.ro \\ 2 Spiru Haret University, Unirii 32-34 Street, 900532, Constanta, \\ Romania, Tel: +40241545015; Email: claudiu.chiru@spiruharet.ro \\ ${ }^{3}$ Spiru Haret University, Unirii 32-34 Street, 900532, Constanta, \\ Romania, Tel: +40241545015; Email: mihaela.bebeselea@spiruharet.ro
}

How to cite: PATACHE, L., CHIRU, C., \& BEBEȘELEA, M. (2018). RURAL EMPLOYMENT AND DECENT WORK IN ROMANIA. Annals of Spiru Haret University. Economic Series, 18(2), 53-62. doi: https://doi.org/10.26458/1822

\footnotetext{
Abstract

The aim of this paper is to study the Romanian rural employment and its perspective to achieve the decent work goals. The United Nation's 2030 Agenda for Sustainable Development aims to 'promote sustained, inclusive and sustainable economic growth, full and productive employment and decent work for all' (Goal 8 of 17, 2015). The decent work is a desideratum that reflects on the wellbeing of the population. The ILO's Rural Employment and Decent Work Programme aims at minimizing rural decent work deficits that include higher rates of un- and under-employment (especially among youth and women); an alarming prevalence of child labour; a higher incidence of precarious work as wage work is mostly seasonal or casual; widespread informal activities; limited social protection; exposure to adverse working conditions due to poor labour standards coverage and monitoring; and little or no unionization or social dialogue.
} 


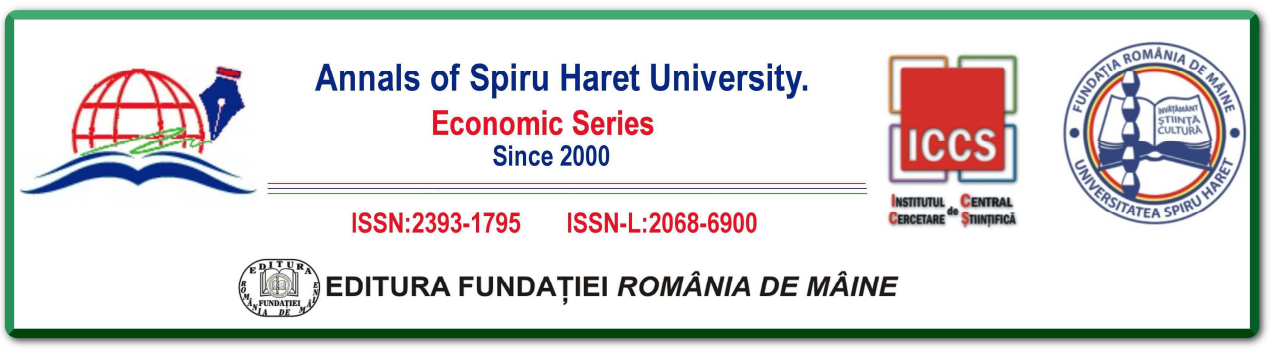

Issue 2/2018

Keywords: rural development; decent rural employment; rurality; predominantly rural regions; significantly rural regions.

JEL Classification: $\mathrm{E}_{24}, \mathrm{~J}_{80}, \mathrm{O}_{18}$

\section{Introduction}

The different perception on 'rural area concept' approached by national administrations, international organizations, policymakers and researchers generates economic, social and policy implementation issues. [See Paszto et al, 2015]

The Romanian Law no. 351/2001 named 'rural locality (village) the area where the majority of the workforce is concentrated in agriculture, forestry, fishing, providing a specific and viable way of life for its inhabitants, and which, through its modernization policies, will also preserve its rural features or the majority of the workforce is in fields other than agriculture, forestry, fishing, but currently offers insufficient equipment to declare it as a city and which, through its upgrading and modernization policies, will be able to evolve to the urban localities.'

National Rural Development Programme (NRDP) 2014-2020 defined 'the rural area as the total of the communes at the level of the administrative-territorial unit, the commune being the lowest administrative-territorial unit, NUTS 5 level'.

As an example, from NRDP point of view, villages belonging to municipalities and towns are not eligible to access funds through the programme as villages are components of communes (the only ones considered as rural area).

Starting from the Report on Decent work (1999), International Labour Office (ILO) has promoted decent work for all, regardless of race, creed, sex or country of origin. Decent work sums up the aspirations of people in their working lives as 'opportunities for women and men to obtain decent and productive work in conditions of freedom, equity, security and human dignity'. [ILO, 1999]

Ribeiro et al (2016) used the conception of "working" instead of "work," as "working" is a more dynamic and structuring conception that indicates action and process in a given context (verb representing an action), while "work" is a more abstract, stable and structured conception constructed in a given context and incorporated in others (substantive representing a state). Hence, "working" represents the abstract concept of "work" in action through human activities in a specific socio-historical context. By decent work point of view, the conception of 


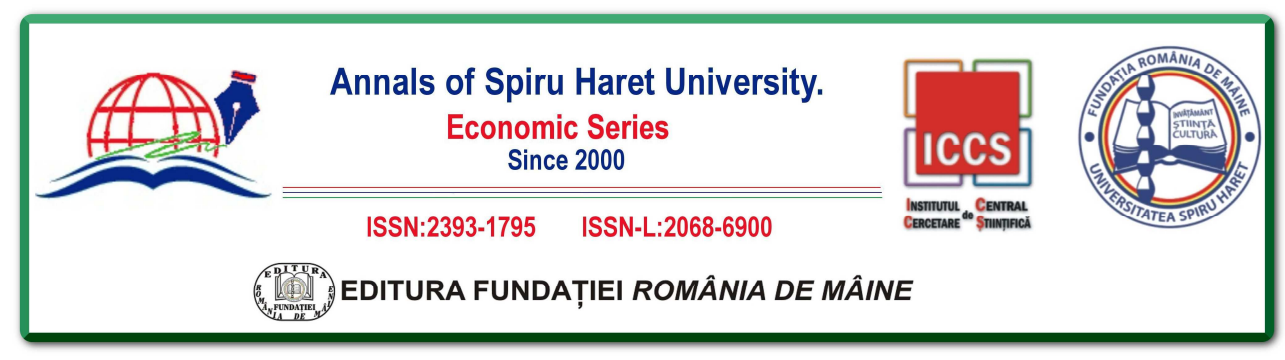

Issue 2/2018

'working' is considered more appropriate than the employment's one, that often excludes multiple coexisting forms of working (informal). [Ribeiro et al, 2016]

Based on macro-indicators, most scholars analysed the employment opportunities for decent work such as: higher labour force participation rate (activity rate) and employment-to-population ratio and low unemployment rate [Anker et al, 2002; Ghai, 2003], even if 'decent work remains a very broadly defined concept, which is impossible to measure across countries' [Burchell et al, 2014].

Through the recently developed Psychology of Working Theory that describes how decent work leads to need satisfaction, work fulfilment, and wellbeing, there are scaled 5 components of decent work: (a) physically and interpersonally safe working conditions, (b) access to health care, (c) adequate compensation, (d) hours that allow for free time and rest, and (e) organizational values that complement family and social values. [Duffy et al, 2017]

The labour market in our country still has an important informal component that contravenes to the principles of decent work, a higher employment at risk of poverty, an imbalance between labour market demand and educational supply and a social protection system that works inappropriately in many ways. [Patache \& Bebeșelea, 2017]

According to the ILO's report The World Employment and Social OutlookTrends 2016, in spite of its relative prosperity, Europe faces very high levels of long-term unemployment in the region that raise serious concerns about the deficit of adequate quality employment creation. So, to achieve target 8.5 on full and productive employment and decent work for all by 2030, European countries will need a comprehensive approach to restore growth and address deficits in job quality [ILO, 2016]. Romania, classified among emerging economies of Eastern Europe, registered lower unemployment rates than Northern, Southern and Western Europe but negative employment growth, too [ILO, 2016]. This information reveals limits in determining the unemployment rates due to the method of data collection (e.g. only the persons who need support in finding a job by the National Agency for Employment were registered). Also, the rural workers unable to find a job are extremely numerous.

Youth unemployment has increased dramatically in recent years. The percentage of young people without a job, or not in education or training, is much higher in rural areas than elsewhere. Exodus of young people is one of the most pressing issues for any future sustainability of rural communities. Young people's 


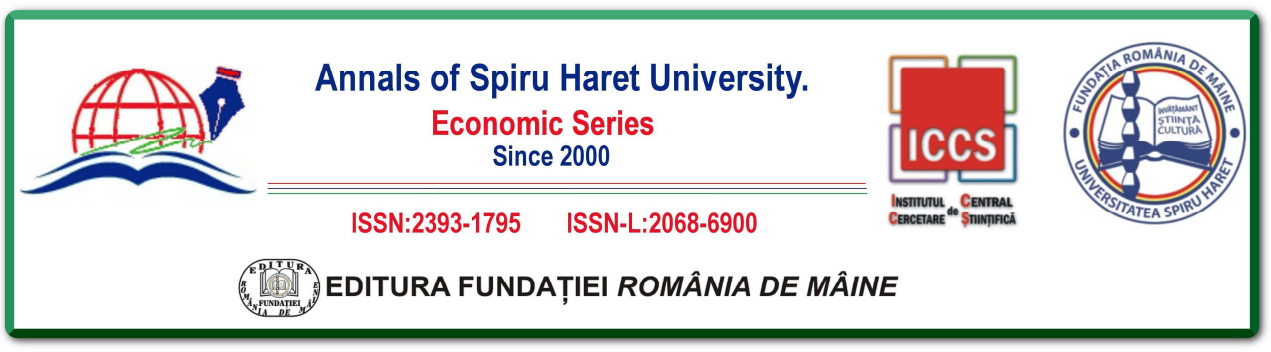

Issue $2 / 2018$

migration decisions are influenced by the geography of the locality, the social setting, the level and the degree of accessibility to infrastructure, the provision of social services, the condition of the local labour market and the role of family, friends and social networks. [European Commission, 2017]

'In order to combat social exclusion and poverty, the Union recognises and respects the right to social and housing assistance so as to ensure a decent existence for all those who lack sufficient resources, in accordance with the rules laid down by Union law and national laws and practices.' [The European Parliament, the Council and the Commission, 2016, art. 34 (3)]

\section{Romanian Rural Employment}

According to Romanian National Institute of Statistics (NIS), in the rural area, on 1 July 2017, there were 2,861 communes with 12,487 villages and 470 villages are belonging to municipalities and cities. In this area, $46.39 \%$ of total population $(9,113,095$ persons) lives with 3.47 p.p. less than in 2008 , but with a higher share in total. Depopulation of rural area is accompanied by the decreasing of working-age population due to the migration and the aging of population. (Figure no. 1)

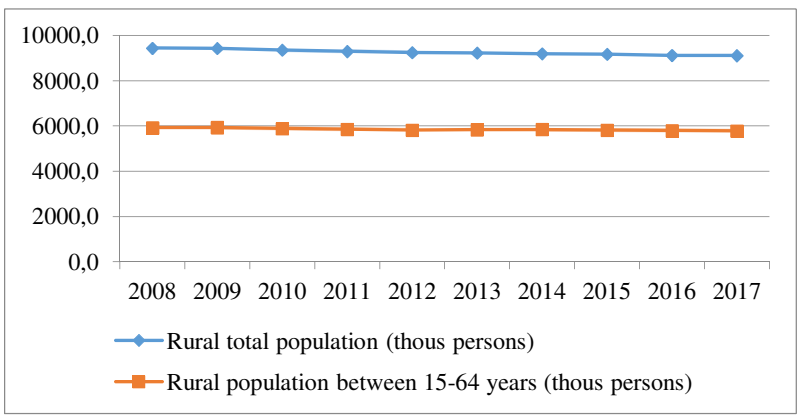

Figure no. 1. Romanian rural population, during 2008-2017 


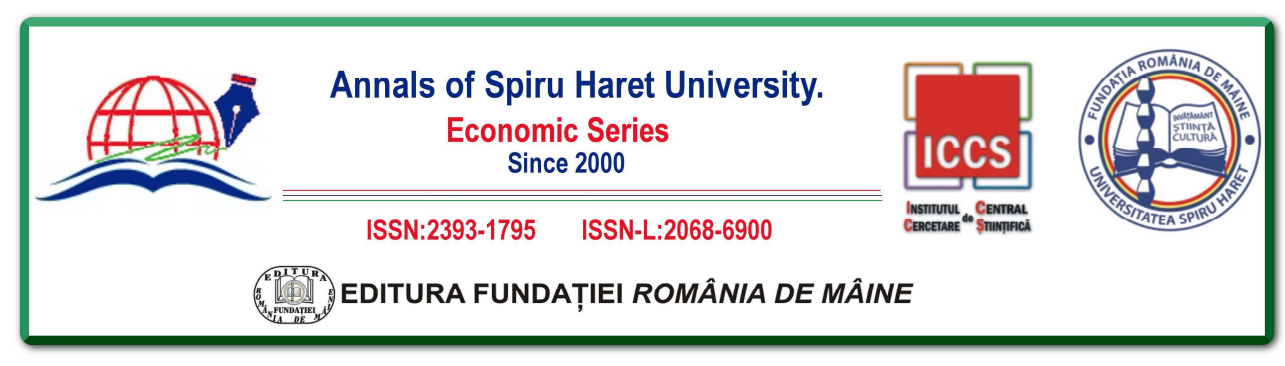

Issue 2/2018

Source: Tempo database, Romanian National Institute of Statistics (NIS), http://statistici.insse.ro

In several studies is pointed out the fact that education, health and the quality of public services in rural areas are at lower level than in urban Romanian areas. [Zamfir, 2017, Badiță et al, 2015, Patache et al, 2015; Chipea et al, 2013, Kerekes \& Pakucs, 2013; and others]

Regarding the Romanian human capital in the latest years (based on NIS Census data), a phenomenon of human capital polarization was registered. 'It means that in the post-communist period, Romania displays a contemporaneous increase in the share of people with tertiary education and an increase in the share of people with lower secondary education at most. Moreover, educational attainment by area of residence indicates that this polarization tends to widen the gap between an educated urban area and a poorly educated rural area.' [Zamfir, 2017]

Table no. 1. Macroeconomic indicators in rural areas

\begin{tabular}{|c|c|c|c|c|c|c|c|c|c|}
\hline Indicators & 2008 & 2009 & 2010 & 2011 & 2012 & 2013 & 2014 & 2015 & 2016 \\
\hline Rural total population (thous persons) & 9441.1 & 9429.1 & 9352.6 & 9296.8 & 9242.3 & 9229.5 & 9200.5 & 9172.5 & 9124.5 \\
\hline $\begin{array}{l}\text { Rural population between } 15-64 \text { years } \\
\text { (thous persons) }\end{array}$ & 5920.9 & 5932.9 & 5885.7 & 5851.3 & 5817.3 & 5840.4 & 5842.4 & 5819.3 & 5791.0 \\
\hline Active rural population (thous persons) & 4588.0 & 4474.0 & 4317.0 & 4131.0 & 4195.0 & 4180.0 & 4165.0 & 4146.0 & 4017.0 \\
\hline $\begin{array}{l}\text { Employment in primary sector (thous. } \\
\text { persons) }\end{array}$ & 2407.4 & 2410.7 & 2439.9 & 2442.0 & 2510.0 & 2380.1 & 2304.1 & 2003.1 & 1726.8 \\
\hline $\begin{array}{l}\text { Labour productivity in agriculture } \\
\text { (USD/employee) }\end{array}$ & 4858.6 & 3836.9 & 3137.8 & 4328.6 & 3024.2 & 3989.2 & 3727.9 & 3307.6 & 3654.1 \\
\hline Net investment in total(mil. USD) & 39512 & 24576 & 22749 & 28805 & 25688 & 24294 & 25726 & 24687 & 23687 \\
\hline $\begin{array}{l}\text { Net investment in the primary sector } \\
\text { (mil. USD) }\end{array}$ & 1347.1 & 957.4 & 837.0 & 1077.6 & 972.2 & 1279.3 & 1311.1 & 1331.5 & 1076.9 \\
\hline GDP/capita (USD) & 10290 & 8404 & 8182 & 9094 & 8499 & 9520 & 9976 & 8925 & 9472 \\
\hline GDP of primary sector (mil. USD) & 13144 & 10804 & 9884 & 10994 & 8092 & 10294 & 9302 & 7543 & 8065 \\
\hline GDP of primary sector ( $\%$ of total) & $6.9 \%$ & $6.9 \%$ & $6.6 \%$ & $6.8 \%$ & $5.4 \%$ & $6.1 \%$ & $5.3 \%$ & $4.8 \%$ & $4.8 \%$ \\
\hline ILO rural unemployed (thous persons) & 212.1 & 238.1 & 208.6 & 225.6 & 208.2 & 218 & 219.8 & 273.5 & 251.7 \\
\hline ILO unemployment rate & 5.6 & 6.5 & 7 & 7.2 & 6.8 & 7.1 & 6.8 & 6.8 & 5.9 \\
\hline ILO rural unemployment rate & 4.6 & 5.3 & 4.8 & 5.5 & 5 & 5.2 & 5.3 & 6.6 & 6.3 \\
\hline NEET $\%$ & 15.6 & 14.1 & 16.2 & 19.2 & 20.0 & 20.1 & 20.5 & 20.0 & 21.1 \\
\hline NEET nural areas $\%$ & n.a. & 19.1 & 23.1 & 24.7 & 24.8 & 25.1 & 25.3 & 25.2 & 25.9 \\
\hline $\begin{array}{l}\text { Average monthly nominal net eamings } \\
\text { (USD) }\end{array}$ & 520 & 446 & 438 & 474 & 435 & 474 & 507 & 464 & 504 \\
\hline $\begin{array}{l}\text { Average monthly nominal net eamings } \\
\text { by primary sector (USD) }\end{array}$ & 363 & 330 & 322 & 342 & 315 & 354 & 379 & 342 & 399 \\
\hline Exchangelew/USD & 2.519 & 3.049 & 3.178 & 3.049 & 3.468 & 3.328 & 3.349 & 4.006 & 4.059 \\
\hline
\end{tabular}

Source: Authors calculation based on Tempo database of NIS and the National Bank 


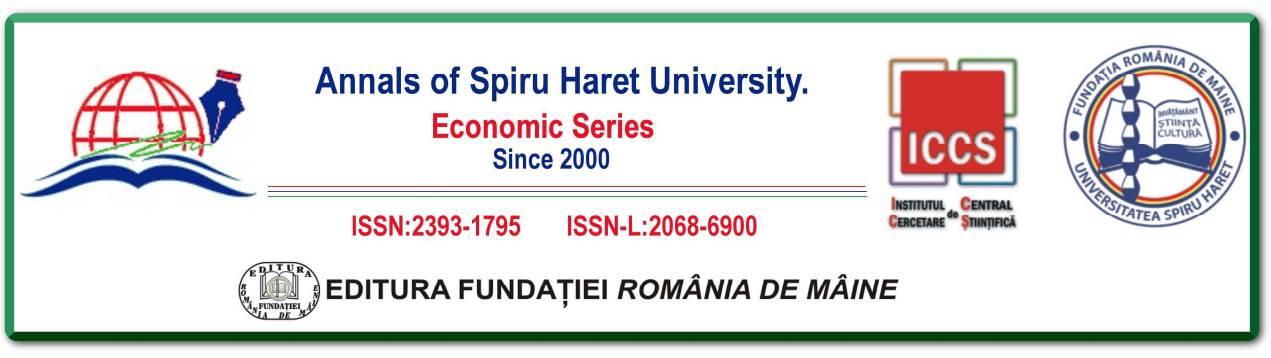

Issue $2 / 2018$

of Romania

The Eurostat regional yearbook mentions that at least half of the rural population in Romania was at risk of poverty or social exclusion in 2015; most of the Member States that joined the EU in 2004 or more recently recorded a higher risk of poverty or social exclusion among their rural populations than in cities or in towns or suburbs. [EUROSTAT, 2017]

The gap between urban and rural areas is highlighted by: low average monthly income with an important 'in kind' component (about one-third, 257 USD in 2017); higher risk of poverty or social exclusion; fewer years of schooling and low education's quality; higher rate of youth neither in employment nor in education and training (NEET), age group 15-34 (25.9\% in 2016) and so on.

Due to the economic and financial crisis and depreciation of the national currency, the Romanian GDP per capita in USD significantly decreased from 10,290 USD/capita (2008) to 8,925 USD/capita (2015). During 2015-2017 the GDP per capita followed an ascendant trend to 10,704 USD/capita in 2017. (Table no. 1)

The decline in the Romanian rural population is accompanied by the decreasing in working-age and active population, but an increase in the inactivity rate.

Regarding the structure of employment in primary sector by professional status, about $49 \%$ are self-employed and other $43 \%$ of total are unpaid family workers and only $7.2 \%$ are employees even if the employees' number increased at $20 \%$ during 2008-2016.

If employment in the private ownership represented $83 \%$ of total in 2016 , the employment in agriculture, forestry and fishing was about $98 \%$. At present, the main form of agricultural holding is the small peasant household, with an average area of 1.95 ha of agricultural land, accounting for $53.5 \%$ of the country's agricultural area. The agricultural units with legal personality have an average area of 190.8 ha and own $42 \%$ of the country's agricultural area, as evidenced by the Agricultural General Census in 2010 at the country level.

The low level of labour productivity and its unfavourable evolution in the primary sector (see Table no. 1) is also a vulnerable point of rural development. The evolution of the average monthly nominal net earnings is not correlated with the labour productivity in primary sector but the last one is correlated with net investment in the primary sector (correlation coefficient is 0.689 ) and specific GDP (0.524) and both have a downward trend during 2008-2016. 


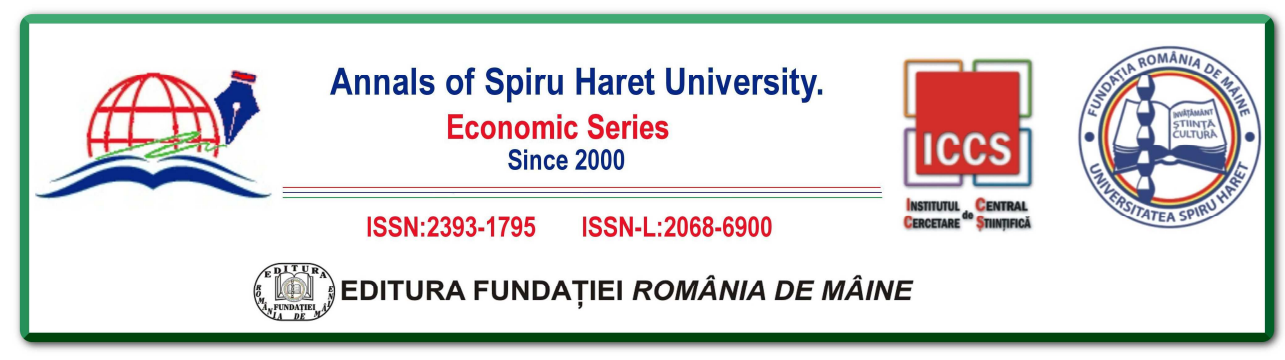

Issue 2/2018

Long term unemployment, living in rural areas and poverty are the key factors that can generate not just economic problems, but also physical and mental health problems. So, 'the risk factors for depression in both groups (employed and unemployed) are: female gender, age between 51 and 55 years old, divorced, living in rural area, low level of education and poverty' [Mihai et al, 2014]. From this point of view, long-term unemployment disguised as inefficient or unpaid selfemployment is one of the main characteristic of rural environment.

\section{Perspectives for decent rural employment}

Decent rural employment in Food and Agriculture Organization of the United Nations (FAO) vision emphasizes six priority dimensions that are crucial to achieving decent work in rural areas:

$\checkmark$ respects the core labour standards as defined in ILO Conventions (is not child labour; is not forced labour; guarantees freedom of association and the right to collective bargaining, and promotes the organization of rural workers; no discrimination at work on the basis of race, colour, sex, religion, political opinion, national extraction, social origin or other);

$\checkmark$ provides an adequate living income;

$\checkmark$ entails an adequate degree of employment security and stability;

$\checkmark$ adopts minimum occupational safety and health (OSH) measures, which are adapted to address sector-specific risks and hazards;

$\checkmark$ avoids excessive working hours and allows sufficient time for rest;

$\checkmark$ promotes access to adapted technical and vocational training. [FAO, 2016]

Despite of Decent Work Agenda for Romania that promotes elimination of trafficking and other worst forms of child labour, it is a fact that the poverty prevalent in rural villages forces many children to work. Though it is estimated that today only $1 \%$ of children are working in Romania, this number is still a concern.

By the fact that employment in rural areas is overwhelmingly based on selfemployment and unpaid family workers, it have no sense to spoke about a collective bargaining or other forms of organization for Romanian rural workers.

In rural areas, the day labourers are widely hired but not with legal forms. Order no. 831/600 of 2015 issued by the Minister of Labour on the approval of the Methodological Norms for the Application of Law 52/2011 on day labourers' sets out specific measures for the protection of day labourers and to ensure health and safety at work for these workers, but the contracts for hiring day labourer are rarely used. 


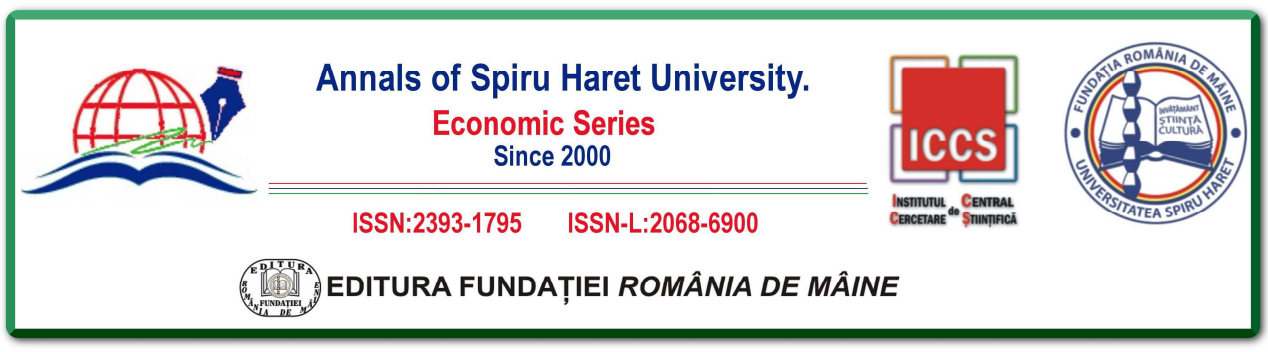

Issue 2/2018

Romania has the highest percentage of adults who are at risk of poverty despite being in work in the EU. Also, in-work poverty is higher among people in non-standard employment and among the self-employed without employees. [Eurofound, 2017]

People living in rural areas are generally more inclined to leave education or training early, in many cases due to the fact that they are not supported to continue their studies and do not have the financial resources and the necessary school infrastructure.

\section{Conclusions}

Romanian rural employment is precarious and far from meeting the standards of decent work.

Employment of about $20 \%$ of the population in the primary sector of activities that contributes only $4.7 \%$ to national GDP, it cannot ensure the conditions of decent work in this sector of activity.

Increasing investment in non-agricultural sectors in rural areas can be a viable solution to poverty alleviation. Measures to support education and health, too, can play an important role in determining life chances and raising the quality of life of an individual. Young people from rural areas are requiring increased attention to not become discouraged or excluded from the labour market.

\section{References}

1. Anker et al., "Measuring Decent Work with Statistical Indicators", Working Paper no. 2 (2002), URL: http://www.ilo.org/wcmsp5/groups/public/---dgreports/---integration/ documents/publication/wcms_079089.pdf.

2. Badita et al, "Challenges for human capital and sustainable development of rural areas. A case study on Craiova Metropolitan Area, Romania", Carpathian Journal of Earth and Environmental Sciences, 10(3), (2015): 101-112.

3. Burchell et al., "The Quality of Employment and Decent Work: definitions, methodologies, and ongoing debates", Cambridge Journal of Economics, 38, (2014): 459-477.

4. Chipea, F., Oşvat, C. and Marc, C., "The Assessment of Health Services for Children in Romania", Review of Research and Social Intervention, 41, (2013): 40-59.

5. Duffy et al, "The Development and Initial Validation of the Decent Work Scale", Journal of Counselling Psychology, 64(2), (2017): 206-221. 


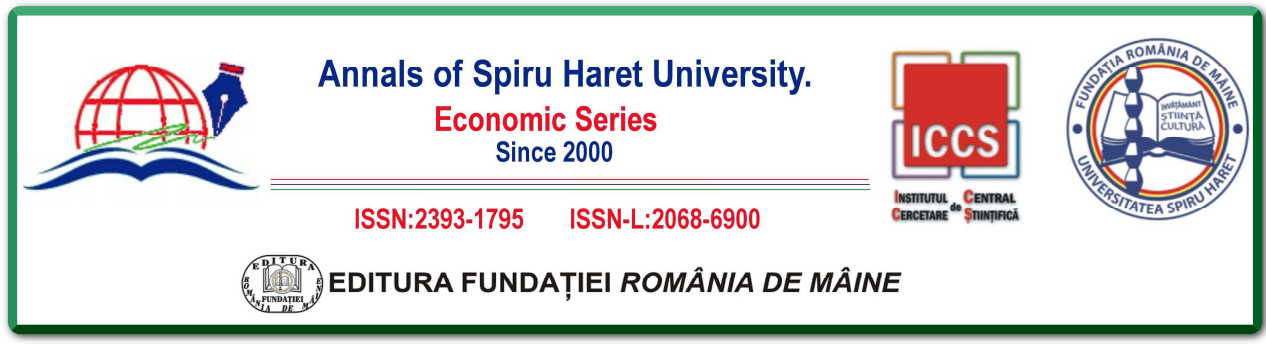

Issue 2/2018

6. Eurofound, In-work poverty in the EU (Luxembourg: Publications Office of the European Union, 2017).

7.European Commission. Directorate-General for Agriculture and Rural Development, Modernising and Simplifying the CAP. Socio-Economic challenges facing EU agriculture and rural areas (11 December 2017), URL: https://ec.europa.eu/agriculture/sites/ agriculture/files/consultations/cap-modernising/soc_background_final_en.pdf

8. EUROSTAT, Eurostat regional yearbook (2017), URL: http://ec.europa.eu/eurostat/ statistics-explained/index.php?title=Eurostat_regional_yearbook.

9. FAO, The State of World Fisheries and Aquaculture 2016. Contributing to food security and nutrition for all. (Rome, 2016), URL: http://www.fao.org/3/a-i5555e.pdf.

10. Ghai, D., "Decent work: Concepts and indicators", International Labour Review 142(2) (2003): 113-145.

11. ILO, Decent work, (Geneva: International Labour Conference 87th Session, 1999), URL: http://www.ilo.org/public/libdoc/ilo/P/09605/09605(1999-87).pdf, accessed on 20 March 2018

12. ILO, The World Employment and Social Outlook - Trends 2016 (2016), URL: http://www.ilo.org/wcmsp5/groups/public/---dgreports/---dcomm/---publ/documents/ publication/wcms_443480.pdf.

13. Kerekes, K. and Pakucs, B., "Occupational Choices of Romanian Rural Youth", Eastern European Countryside, 19, (2013): 57-76.

14. Mihai, A., Ricean, A. and Voidazan, S., "No Significant Difference in Depression Rate in Employed and Unemployed in a Pair-Matched Study Design", Public Health 2 (2014), URL: https://www.ncbi.nlm.nih.gov/pmc/articles/PMC4109612/\#B1.

15. Patache, L., "Trends in youth employment: Romania case of study", Ecoforum 4 (Special Issue 1) (2015): 147-152.

16. Patache, L. and Bebeșelea, M., Aspects regarding the Quest for Decent Job for Romanian Worker, (Constanta: International Conference on Law and Social Order LSO 2017, 20-21 October 2017).

17. Paszto et al, "Using a fuzzy inference system to delimit rural and urban municipalities in the Czech Republic in 2010", Journal of Maps 11:2 (2015): 231-239. URL: https://www.tandfonline.com/doi/full/10.1080/17445647.2014.944942

18. Ribeiro et al, "Discussing the Notion of Decent Work: Senses of Working for a Group of Brazilian Workers without College Education", Frontiers in Psychology 7 (2016), URL: file:///C:/Users/User2/Downloads/fpsyg-07-00207.pdf

19. The European Parliament, the Council and the Commission, "Charter of Fundamental Rights of the European Union", Journal of the European Union C 202/390/7.6.2016. 


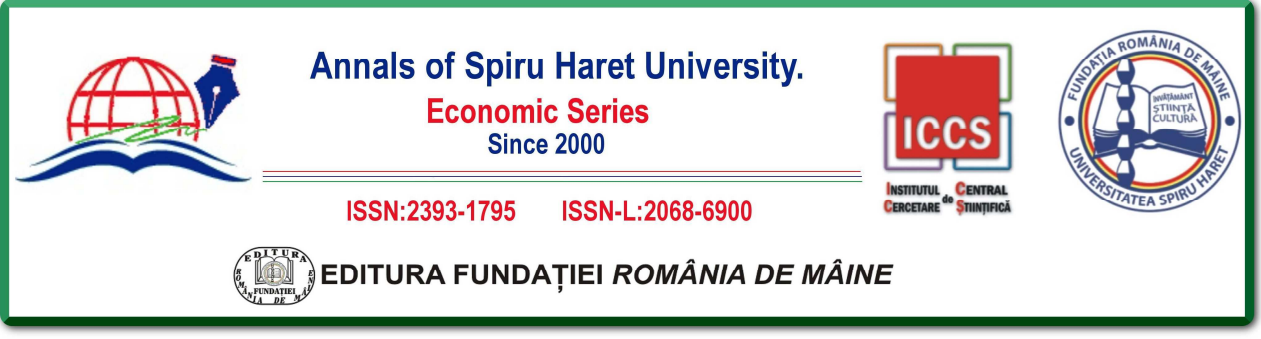

Issue 2/2018

20. The Romanian Parliament, "Law no. 351 on the approval of the National Territory Planning Plan - Section IV of the Localities Network", Official Gazette 408/24 July 2001, updated April 2018.

21. Zamfir et al, "Spatial Inequalities in Health Care Provision in Romania: Milestones for Territorial Sustainable Development", Carpathian Journal of Earth and Environmental Sciences 10(3) (2015):177-188. Indexat ISI

22.Zamfir, A.M., Urban-Rural Educational Inequalities and Human Capital Polarization in Romania. Revista Romaneasca pentru Educatie Multidimensionala, 9(3) (2017): 157165 . 